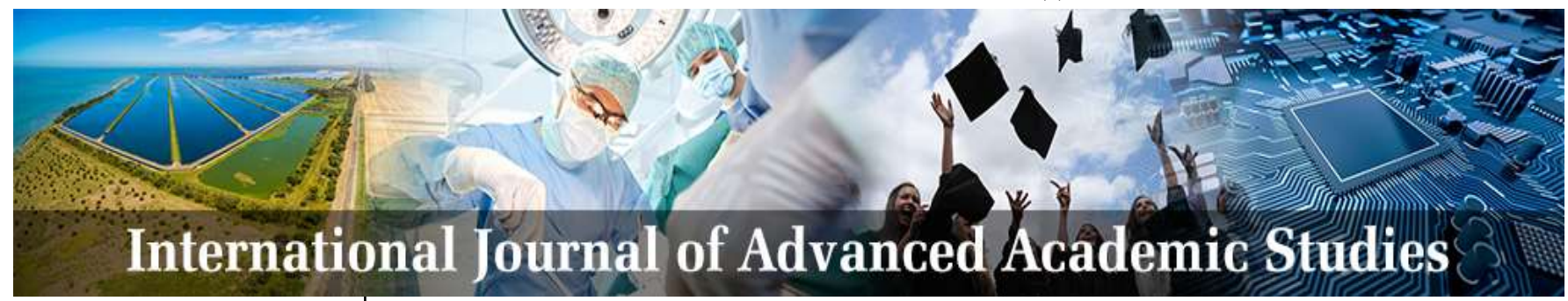

E-ISSN: 2706-8927

P-ISSN: 2706-8919

www.allstudyjournal.com

IJAAS 2022; 4(1): 14-23

Received: 08-11-2021

Accepted: 12-12-2021

Ahmad Jawad Niazi Assistant Professor,

Department of Architecture,

Kabul Polytechnic University,

KPU Campus, 5th District,

Kabul, Afghanistan

Saleh Mohammad Yari

Professor, Department of

Architecture, Kabul

Polytechnic University KPU

Campus, 5th District, Kabul,

Afghanistan
Corresponding Author:

Ahmad Jawad Niazi

Assistant Professor,

Department of Architecture,

Kabul Polytechnic University,

KPU Campus, 5th District,

Kabul, Afghanistan

\section{A study on creation of new towns and their development in the postwar era: Founding ideas and forms of new towns}

\author{
Ahmad Jawad Niazi and Saleh Mohammad Yari
}

DOI: https://doi.org/10.33545/27068919.2022.v4.i1a.675

\begin{abstract}
In order to decentralize large cities (metropolitan areas) that have population overflows and limitations in physical expansion, the creation of new towns with dependent, independent, or satellite identities is one of the dominant ideas among urban experts and urban planners.

New towns are purposefully planned urban communities that have been established since the beginning of the twentieth century to solve the demographic (overcrowding and congestion of large cities) and economic problems of metropolitan areas and countries. New towns are created in rural or undeveloped areas to be self-sufficient and mostly their land is transformed from rural to urban. New towns are constructed within a predetermined period of time generally with government sponsorship.

The purpose of this article is to examine the need to create new towns and to identify their developments in the Post-War era (1945 onwards) in different countries with different perspectives and programs.

According to the outcomes of this research and a look at the experiences of different countries in the creation of new towns, it can be said that in countries where the need to build and locate new towns has been in line with their comprehensive national and regional policies, also using the support of private and governmental policies (such as preparation, lending, land, etc.) draw the attention of planners for considering the jobs needed and other reasonable needs of immigrants in the new towns. Respectively, such things have led to the success of creating various forms of new towns (independent towns, satellite towns, dependent towns).

In contrast, countries that have created new towns, regardless of their cultural and territorial functions, from one hand and the lack of necessary infrastructure, as well as the lack of provision for financing, job opportunities, and other needs in such towns, on the other hand, such countries did not have much success in the formation and expansion of new towns.
\end{abstract}

Keywords: New towns, post-war era, urbanization, urban planning

\section{Introductions}

One of the methods of decentralization in cities is spatial decentralization based on the creation of new towns. From the beginning of the New Towns movement of the post-war era (after World War II) and based on the theory of the garden cities and by following the British experience in the creation of new towns, many countries of the world have been created different types of new towns.

Generally, in the category of new towns, the main problem is to build a real city in a relatively short period of time (a few years), while existing cities have taken decades or maybe centuries to build over time. Another issue that needs to study is that how Its inhabitants quickly should feel like living in a real city, a city that has harmony and identity, otherwise the rapid construction of thousands of housing units in the complex is quite easy with the current techniques and technology. (Pierre Merlin, 1971) ${ }^{[20]}$.

Although the initial thought and movement of creating new towns go back to the distant past, nonetheless the most important difference between contemporary new towns and new towns of the past should perhaps be sought in their role or function, because in the past there was never been raised an issue called new towns for acceptance of overflow Population. But today, major new towns are being created and expanded to guide the overflow of mother cities (and to decentralize them).

New towns, although not hindering the urban growth of large cities, but have slowed the growth process and distributed population in spaces. This factor can be led to success for such towns; however, the plan to create new towns has been successful in some countries 
and unsuccessful in others.

Thus, Considering the demographic changes of recent decades, this article seeks to find answers to these questions, what are the need for planning and the creation of new towns? Will the policy-making and oversight of governments and the greater presence of the private sector in the implementation of new towns, the construction of new towns be more successful? Is it possible to expect more success in the development of various forms of such towns with proper planning and taking into account the needs of potential immigrants entering new towns? Finally, what are the reasons for the success or failure of new towns in the post-war era?

\section{Methodology}

The methodology for this study is reviewing prior works of literature and examining the forecasts in urban planning and population distributions in cities, to find out the need for creating new towns and examine the evaluation of new towns in the post-war era.

The lessons from each county and their experiences in the creation of new towns are assessed, through which the need for decentralization has been wished-for. Moreover, the forms, policies of special planning, and typology of new towns have been determined by the evaluation of new towns in some counties. The following flow chart shows the procedure for this study (Figure 1).

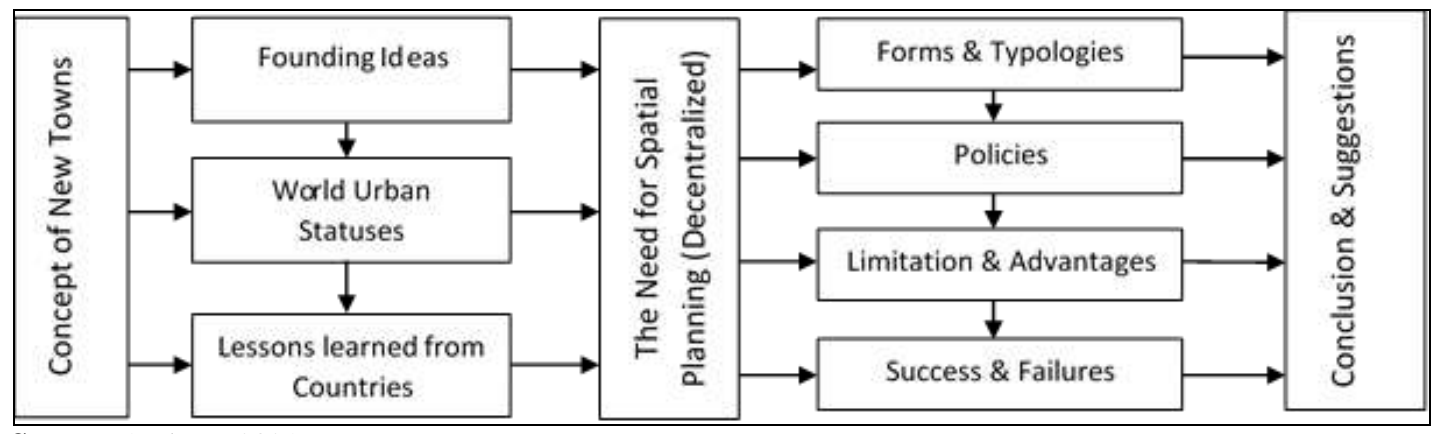

Source: Authors, 2021

Fig 1: The methodology

\section{The founding ideas in the creation of new towns}

In terms of the source of growth, cities have either had selfgrowth or have been designed and built according to the plan. Basically, the need to create new towns arises during the transition and transformation of societies (Keramatullah Ziyari, 1999) ${ }^{[13]}$.

After the Industrial Revolution, the goals and necessity of the formation of new towns changed, consequently that the increase in population, rural-urban migration, the physical expansion of cities, and the emergence of metropolitans, led to new theories about new towns.

In 1882 Soria Y. Mata introduced the theory of a Linear City (LA Ciudad Linear) in order to expand the urban fabric, according to which the city continues along with the communication network in a linear manner, and the residential and industrial areas are located on either side of these lines; And during his lifetime, his dream was formed only in one of the small suburbs of Madrid ( جواد شهيدى، 1377 [3وروش,

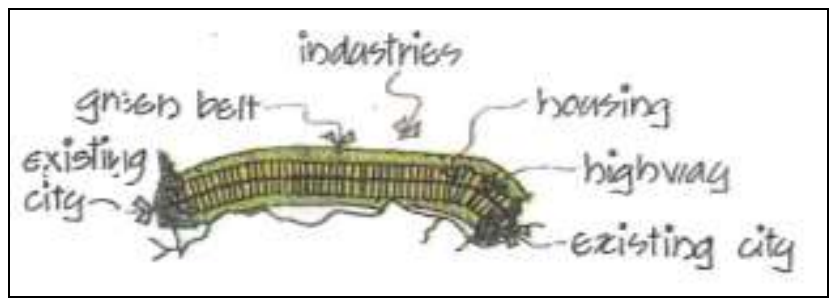

Fig 2: Linear City, (Abir Bandyopadhyay, 2010) ${ }^{[1]}$

In 1898 Ebenezer Howard coined the theory of Garden City, He believed that by creating several garden towns around large cities, we should decentralize such cities. (Calloway \& Faghri, 2020) ${ }^{[9]}$. In the same era, the theory of Industrial City (LA Cite Industrielle) was proposed by Tony Garnier. He was fascinated by the architectural pattern of twentieth-century cities which could meet the needs of social and technical developments. He implemented his theory in Lyon, France, on a small scale. (Ostrowski, 2000) [19].

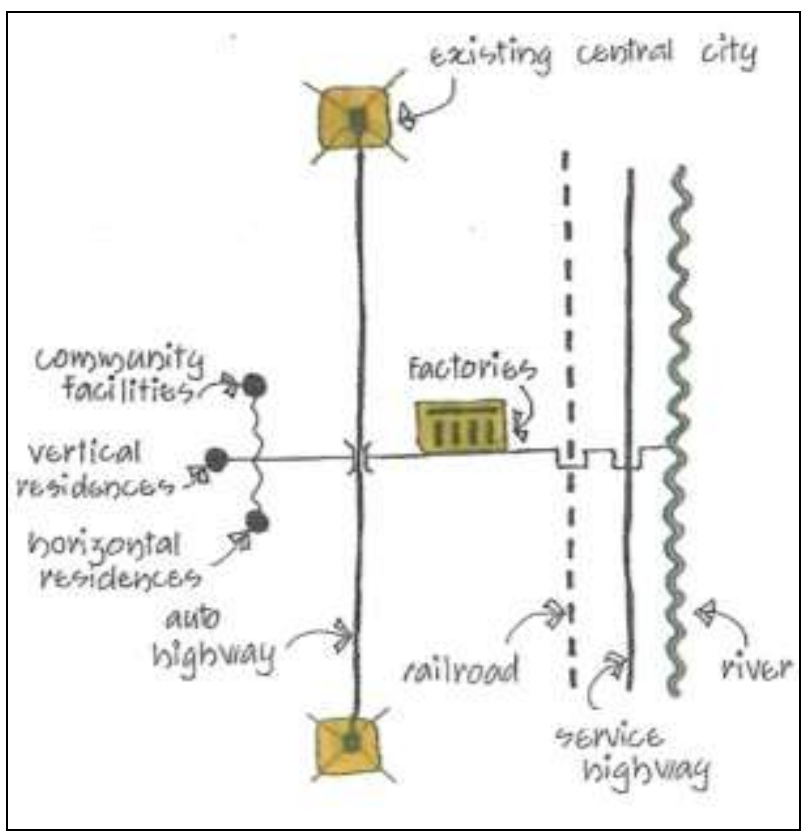

Fig 3: The Industrial City (Abir Bandyopadhyay, 2010) ${ }^{[1]}$

Charles-Édouard Jeanneret nicknamed Le Corbusier, presented his ideas in Concentric City (1922), Plan Viosin (1925), and The Radiant City (1930), he introduced a new vision in the construction of skyscrapers in the new towns, and the planning philosophy was creating urban surroundings as definitely contrasting to the rural areas and he believed that densities themselves are no problems, highdensity living should provide for the classified street system. 


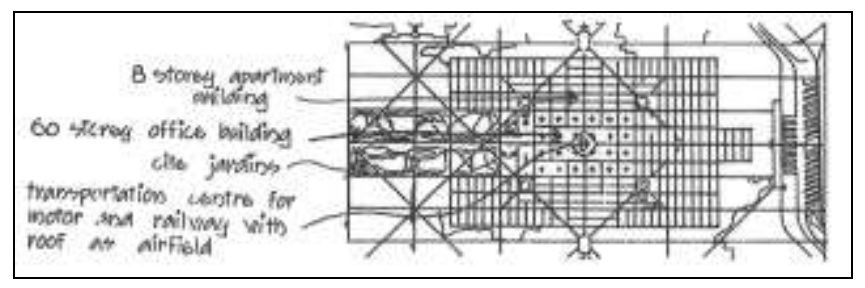

Fig 4: Contemporary City (Abir Bandyopadhyay, 2010) ${ }^{[1]}$

In 1923, based on the needs and necessities of new towns, Clarence A. Perry and Clarence Stein framed the theory of the Neighborhood Unit, which provides the necessary services at the local community scale and it is defined as a physical environment in which a mother knows that a child will have no traffic streets to cross on his way to school, which is within easy walking distance from home. (Niazi, 2021) ${ }^{[18]}$.

Finally, on the eve of World War II (1939-1945), and in fact, at the end of this war, models of new towns were proposed and designed, which are known as the new جو اد شهيدى، ( generation of new towns of the post-war era. (كوروش, 1377 .

The beginning of the developing new towns of the post-war era should be considered from England and the report of the
Barlow Commission (1937). In that report, the inadequacies and problems of concentration in the city of London from a strategic, social, and economic point of view were discussed. (Pierre Merlin, 1971) ${ }^{[20]}$. The principles of Barlow's report were considered by Leslie Patrick Abercrombie in the Greater London Plan (1944). He suggested that 10 new satellite towns should be built around London to implement the decentralization policy. (Keramatullah Ziyari, 1999) ${ }^{[13]}$.

From this date onwards, the construction of new towns in other countries of the world was proposed and continued mainly in order to decentralize the mother cities (metropolitans).

\section{Increasing urbanization and the need to decentralize metropolitans}

In general, the measurements show that the proportion of the world's urban population is increasing. According to statistics in 1800 the world urban population was 2.3 percent, in 1850 it was 9.6 percent, in 1900 was 31.6 percent, in 1950 was about 29.6 percent and in 2020 was 56.2 percent. It is predicted that this figure will increase to $68.4 \%$ by 2050 (Table 1 ).

Table 1: Evaluation of Urban Population in the World (1950-2050) Source: (United Nations \& Department of Economic and Social Affairs, 2018) ${ }^{[25]}$

\begin{tabular}{|c|c|c|c|c|c|c|c|}
\hline World Population & $\mathbf{1 9 5 0}$ & $\mathbf{1 9 8 0}$ & $\mathbf{2 0 0 0}$ & $\mathbf{2 0 1 0}$ & $\mathbf{2 0 2 0}$ & $\mathbf{2 0 4 0}$ & $\mathbf{2 0 5 0}$ \\
\hline Total Population (Urban + Rural) & 2536275 & 4458412 & 6145007 & 6958169 & 7795482 & 9210337 & 9771823 \\
\hline Urban Population (thousands) & 750903 & 1754201 & 2868308 & 3594868 & 4378994 & 5938249 & 6679756 \\
\hline Urban Population (\%) & 29.6 & 39.3 & 46.7 & 51.7 & 56.2 & 64.5 & 68.4 \\
\hline
\end{tabular}

Furthermore, one of the most important features of urbanization is the concentration of population and the emergence of large cities. This feature became more and more serious in the world with the emergence of cities with a million population of and increasing their share (as a result of increasing the number and expansion of these cities) in the world. However, there was no city with over a million populations until the nineteenth century, and scholars have not been forecasted the creation of such cities. Nonetheless, as a result of the consequences of the Industrial Revolution, including the facilitation of employment and the expansion of means of transportation, as well as the making of countries and cities safer, cities removed their surrounding towers and fortifications and expanded. Subsequently for the first-time cities with millions of populations come across in the Nineteenth century.

In 2035 , it is predicted that there will be 48 large cities (with 10 million people and more) all over the world. Of these, the share of the countries includes 5 cities in Africa, 32 cities in Asia, 3 in Europe, and 8 in America and the Caribbean (Table 2).

The reason for the increase in urbanization and the emergence of large cities in developing countries is population growth in recent decades and also a large wave of migration from rural to urban areas. (Calloway \& Faghri, 2020) ${ }^{[9]}$. The increase in the number of large cities, happens in developing countries while the management structure of these countries has fundamental weaknesses and is not able to provide welfare, comfort, and health for its citizens, and management systems in these countries lack the necessary efficiency, thus, decentralization in different ways is essential to reduce development problems (especially in large cities) of these countries.

Table 2: Number of Agglomerations (Cities) according to the size of urban settlements in the world. Source: (United Nations \& Department of Economic and Social Affairs, 2018) [25]

\begin{tabular}{|l|l|l|l|l|l|l|l|l|l|l|l|l|l|l|}
\hline Size class of urban settlement 1950 & 1980 & 2000 & 2010 & 2020 & 2025 & 2035 \\
\hline
\end{tabular}

\begin{tabular}{|c|c|c|c|c|c|c|c|}
\hline 10 million or more & 2 & 5 & 16 & 25 & 34 & 37 & 48 \\
\hline 5 to 10 million & 5 & 19 & 30 & 39 & 51 & 58 & 73 \\
\hline 1 to 5 million & 69 & 174 & 325 & 380 & 494 & 558 & 639 \\
\hline
\end{tabular}

\section{Forms and policies of spatial decentralization}

It's well-known that one of the characteristics of developed societies and also one of the indicators of development is decentralization. Although some believe in regional balances naturally, and do not see government intervention as an effective approach in decentralization, and articulate any effort in this area as a waste of time and financial resources. However, the effort to balance the urban systems and the need to moderate the flow of migrants to large cities is one of the reasons that justify the use of decentralization policy, because (National solace or peace are obtained as a result of the reasonable settlement of the population and until this solace is not achieved, other development programs will fail). (Bastie, 1997) ${ }^{[7]}$.

Nowadays, many countries pursue decentralization policies in various ways. In general, the strategy of centralized decentralization has become very popular due to environmental considerations and can be considered as the creation of separate towns outside the main city that are connected to each other with proper networking of public transportation. (فريدون \&سول ربانى, 2002) ${ }^{[33] . ~}$

At the beginning of the new towns movement in different 
countries of the world, different spatial planning was done in order to decentralize and regional balances.

These space policies include:

1. Decentralization and transformation of the rural economy;

2. Decentralization and migration control;

3. Industrial decentralization and control of large cities;

4. Decentralization and the role of small towns;

5. Decentralization and creation of new capitals; And

6. Spatial decentralization and creation of new towns 131]

The implementation of various forms of decentralization in different countries of the world has led to different results so that in some cases it has been successful and in others, it has failed.

Generally,centralism to succeed, for decentralization and they must coexist peacefully and support each other, not appear as rivals in the politics of countries; Because the two areinterdependent. (Richard Peiser, 2021) ${ }^{[24]}$

\section{The need for spatial decentralization and the creation of new towns}

Considering the future growth of the urban population, urban development is at the top of the world's urban issues (see Table 2). The most important factor of urban development is responding to the need for housing and urban growth in various dimensions. To prevent urban sprawl, which is not a desirable phenomenon, measures are needed to monitor the natural growth rate of the urban population and control the high rate of migration to cities. The control of urban population growth and regulating the urban population distribution are somewhat very effective. However, if for any reason these two solutions cannot be done or have not been successful, urban development is inevitable.

The types of urban development are as follows

1. Improving and renovating the inner urban fabric of existing cities;

2. Physical growth of existing cities; And

3. Urban sprawl or unwanted expansion of existing cities.

Usually, among the various types of urban development, improvement and renovation of the inner urban fabric of existing cities is the first priority in order to optimally use the urban space. This model has been named as improvement of the urban fabric in the city (The concept of urban fabric improvement in the city reveals a large-scale improvement, modernization, and redevelopment of the core of the city). If the model of improving and renovating the inner urban fabric of existing cities is not enough to increase the urban population, the model of physical expansion of existing cities in a way that should not face natural and artificial constraints is suggested.

In cases where urban development needs are not met through the first two options, the need for accepting urban sprawl or intermittent urban development becomes necessary. If we do not plan for the overflow of the urban population, the cities would expand unplanned and abnormally. Therefore, during the overflow of the urban population (leaving of the two mentioned models), the creation of towns is an inevitable process and if it is not done according to a plan, towns will come into being spontaneous. As a result, in the long term, spending excessive costs to solve the problems of such unplanned cities (informal settlements) will be inevitable.

In such circumstances, the policy of creating new towns due capacity in terms of implementation to its flexible has been and will continue to be considered as a fundamental solution, Therefore, the policy of spatial decentralization based on the creation of new towns, which is known as one of the shortest forms of decentralization in developing countries is chosen as a model of urban sprawl development .(Bora, 2014) ${ }^{[8]}$ The experience of developing new towns in industrialized and developed countries has proved the role of such towns in managing the urban functions and population overflow and achieving the goals of their formation (i.e. decentralization and distribution of the urban population).

Needless to say, new towns take on different functions in spatial decentralization, and their success depends on the overall urbanization policies of governments and careful study of the selection and implementation of this model of urban expansion. In general, in order to be successful, each new town must provide its residents with the jobs they need, meet their daily needs, provide recreational facilities for the people, and finally offer specific housing units for each class and group. (Liu, 2016) ${ }^{[14]}$.

\section{Aims of creating new towns}

The goals of creating new towns in different countries vary according to the needs of their creation and the systems governing the countries. Nowadays the purpose of developing new towns is not only to build the ideal settlements in the history of urbanization (i.e., utopia, perfect city, city of God, city of the sun, city of good citizens, city of health, and clean city) but also the most important aim of creating modern new towns is that (decentralization of urban centers to equally distribute the material and human facilities in all part of the society). (Luo \& Zhang, 2020) ${ }^{[15]}$.

However, some other aims of new towns include: preventing the mother city from too much growing; Transfer of annoying industries from the mother city; Establishment of employment centers in the new towns; Preventing land brokerage in the mother city; Mother city refinement; Reduction of transportation costs from the mother city to the surrounding industrial centers; Prevent the creation of slums and suburbs in the mother city; Reducing the traffic load in the mother city, bringing the place of residence closer to the place of employment in new towns; Prevent the destruction of agricultural lands on the outskirts of large cities; Providing housing for the majority of the people; Reducing the costs of developing the infrastructure of the mother city; Preventing the pollution of the environment of the mother city and using the pristine, empty and low-cost lands around the mother cities as suitable places for population growth ...etc. (Mayunga, 2018) ${ }^{[16]}$.

\section{Limitations and advantages of new towns}

The new towns are a human social phenomenon and each human social phenomenon has its own limitations and advantages. Some of the limitations of new towns include the following:

These towns have a high cost before they become active in functions planned for; As a result, most of them do not have enough investment guarantee in the early stages of formation. In terms of services, they rely on the mother 
cities around them, because the new town, despite numerous supports, cannot be like the mother city, and because it does not have its special charms or grace, thus, cannot easily be self-governed and has to be as a dependent satellite town located next to the mother city.

Furthermore, creating a new town is a kind of unrealistic action in orienting urbanization and directing on the surroundings, which does not show a bright future. As a result, these towns do not solve the problem of migration and marginalization. (Pollalis et al., 2014) ${ }^{[21]}$.

The main advantage of creating new towns is that: Creating new towns is certainly preferable to the unwanted growth of cities and unplanned settlements because in such circumstances there is no considered funding for the development of social infrastructure (including job creation and others) (Rego \& Caleiro, 2010) ${ }^{[23]}$.

Therefore, according to the lack of investment in the construction of new towns, excessive and manifold costs will be imposed on the community in the long run in order to organize unplanned cities or informal settlements. This advantage of new towns (i.e. planning for pre-urban expansion) is a necessary and sufficient condition for the creation of such towns.

\section{Typology and locating the new towns}

The location of new towns is directly related to the goals and systems of construction of new towns. However, in the opinion of the authors it is suggested to pay sufficient attention to the following points in locating new towns:

The creation of new towns should be based on national and regional planning also in line with land management policies, so as not to cause environmental damage; Likewise having an appropriate connection with other cities; Existence of low-cost and acquisition able lands; Closeness to employment centers and the existence of a residential core.

Obviously, in addition to the above factors, the environmental potential of the region and its natural features are also important; However, the role of political factors should not be overlooked. The main typology of new towns includes independent new towns, satellite towns, and dependent (compact) new towns.

\section{Independent new towns}

The main function of this type of new town is to create a regional balance and it is used as a tool in regional studies to stabilize the population in new areas or next to the natural capabilities or potentials that are being exploited. Independent new towns in some Latin American countries, Asia, and Australia have been associated with the 1) stabilizing of populations in undeveloped areas, 2) the emergence of new political divisions, and 3) the relocation of capitals. A perfect example of these new towns is Brasilia (in Brazil), Chandigarh (in India), and Islamabad (in Pakistan). (AEENI et al., 2019) ${ }^{[2]}$.

Independent new towns are planned communities that are created with the goals of 1) decentralizing, 2) exploiting resources, 3) strengthening industrial areas, 4) creating growth poles in undeveloped (backward) areas, 5) regional development, and 6) changing political and service structures in the areas. They have been built in most parts of the world, especially in the former Soviet Union. The distance between these towns and neighboring large cities should not encourage traveling, and at least be more self- reliant and should have their own range of influence. (اداش اشيرنيا اكبرنيا \&يور

\section{Satellite new towns}

The creation of satellite new towns occurs with the expansion of the metropolis and the unbridled growth of large cities and sometimes arises due to the development constraints or limitations of these cities.

These types of towns are small-scale cities that are formed around the mother city. The purpose of creating them is to accept the population of the urban area so that the density of the population in the area is balanced. Satellite new towns are different from the suburbs. (Because such towns are far from the central and main city and may be separated from them, moreover daily movement of people from satellite towns to the central city and vice versa is done on a minor

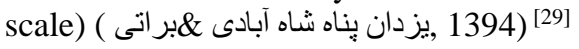

In general, the satellite new towns are within the metropolitan area and have strong functional links with the central city. Therefore, having the proper communication is vital for them and the traveling time should not exceed 30 to 45 minutes. The main principles of these towns are decongestion and they are also called dormitory towns (Keramatullah Ziyari, 1999) ${ }^{[13]}$.

\section{Compact (dependent) new towns}

This group of new towns is within the existing cities and in most cases is linked with the physical growth of main cities. The purpose of creation of them is to solve the problem of residential accumulations, spatial organization, and sparsification of the mother city. These towns have a high population density due to their location within large cities and develop very quickly. Mostof these towns over time merge into the main city and become part of it. (HATAMI NEJAD, 2017) ${ }^{[12]}$

\section{The experiences of some countries in the creation of new towns}

Examining the successful and unsuccessful models of the creation of new towns in the world, considering that the policy of formation of new urban settlements and its expansion has been one of the programs of these countries to decentralize population and create employment. Such experiences can guide and pave the way for future planning in creating new towns in other parts of the world.

\section{The United Kingdom}

The experience of the United Kingdom as a country in which new towns developed in the modern sense after World War II (1945) seems necessary .Experts noted that after the enactment of the British New Towns Act (1946), several generations of new towns emerged in the United Kingdom: the first period (1935-1951) with 10 major urban planning projects; the second period (1951-1961) with the 1 urban planning projects; the third period (1948-1970), with 7 major urban planning projects; and the fourth period (1968-1970) with 5 major urban planning projects performed. (RAZMI \& RAHIMIYOUN, 2013) ${ }^{[22]}$

According to Pere Merlin, "The construction of new towns in Britain is an undeniable success. Loyalty to the original design is undoubtedly commendable, although some points need to be revised. In view of the above scripts, Britain can be considered as one of the countries that have been 
successful in building new towns. It remains to be seen what were the reasons for this relative success.

sufficiency and government support-Financial self:

The British new towns were mostly created by the central government. The British government provided the necessary facilities for the private sector to build factories, shops, and houses, and also allocated financial resources for the construction of the new towns. (Yaran \& Mohammadi Khoshbin, 2012) [26]

The financial resources were given to the construction companies because it was the construction companies, each of which was responsible for building a town; In this way, the development bodies could receive long-term loans (for 60 years) from the government at fixed interest rates for development and manage the finances directly so that they would eventually be able to repay all the loans they received, Therefore, Financial self-sufficiency and government support can be considered the most important factors in the relative success of the creation of British new towns.

\section{Employment along with housing}

Along with having a house in British new towns, employment has been a must. Therefore, in the UK, an organization was created regarding (cooperation and development) to work in this field )employment along with housing). For example, Stevenage, a British new town (1946), has lasted to the present day as an active and efficient example of a stable society. Because $61 \%$ of Stevenage's workforce lives and works in this town. (Fathi \& Ghabelerahmat, 2016) ${ }^{[11]}$

In the field of residential employment, Britain has succeeded in (creating housing units for more than 2 million people and creating jobs for more than 1 million people in more than 32 new towns) Even It can be said that the development of the British new towns was related to changes in employment rate, size of the labor force and immigration to these towns. (AJZA SHOKOUHI, 2003) ${ }^{[4]}$

\section{Satisfying the needs of immigrants with the aim of giving identity to new towns}

To this end, extensive activities were carried out in the following matters. (AJZA SHOKOUHI, 2002) ${ }^{[3]}$

- Providing socio-economic facilities (employment along with housing, education, health services, and welfare facilities);

- The attractiveness of the urban landscape in the form of regulation of various land uses and densities;

- Balance and socio-economic diversity in urban neighborhoods. No separation or segregation of urban neighborhoods based on people's incomes;

- Establishment of a suitable network and fast transportation system (railway),

- Attracting people participation and increasing citizens' welfare.

Thus, the relative success of the British New Towns Act can be summed up in financial self-sufficiency and government support, housing employment, and meeting the needs of immigrants.

\section{South Korea}

In order to solve the problems of urbanization of Seoul (the capital of South Korea), the South Korean government pursued urban policies, and simultaneously implementation of various urban development projects in Seoul. The policy of creating new towns was one of these policies in which the inflation of housing price was the main purpose for the implementation of it. (Keramatullah Ziyari, 1999) ${ }^{[13]}$ After the establishment of this policy within 5 years, 5 new towns were built in the suburbs of Seoul, that all of which were connected by metro to the center of Seoul, and a total of $\$$ 200 billion was invested for their 2,000 residence. The positive achievement of creating new towns in South Korea has been stabilizing housing prices and prioritizing housing quality. Negative points can be considered the shortage of construction materials and labor so that the wages of construction workers doubled from 1989 to 1992, which in turn led to higher wages in the industrial sector.

The result of the creation of new towns in this country has been the attraction of population overflows in the form of dormitories towns along with the provision of housing for employees. (Pierre Merlin, 1971) ${ }^{[20]}$.

The reasons for South Korea's relative success in the formation of new towns have been:

1. The construction of new towns has been done in the form of urban development models and with the support of the government.

2. Essential investment in the field of job opportunities, transportation, infrastructure facilities and equipment, and other needs of the residents has been done before settlements in new towns and after that, the pre-sale of lands and sale of residential units have been done.

\section{The Soviet Union}

The largest number of new towns have been formed in the former Soviet Union. According to a report (since the 1917 Political Revolution, more than 800 new towns have been built in this country. Moreover, in the last 50 years, 35\% of the Soviet Union population has been absorbed by these new towns and 350 new independent towns have been created in underdeveloped areas). (David Friedman, 1989) [10]

The new towns in the Soviet Union were built on a socialist system with the aim of limiting the growth of large cities, strengthening small and medium-sized satellite towns, and shifting industries and populations from the European part to vast areas in the east of the country. This strategy has been done for better utilization of huge oil resources, woods, coal, and hydroelectric power in Siberia as well as the construction of backward and remote areas. (Anthony Alexander, 2009) ${ }^{[6]}$.

In order to decentralize large cities in this country, the relocation of population to other newly established and sparsely populated areas has been done through incentive policies such as increasing salaries and creating job opportunities. On the other hand, policies and encouragements to increase population in Large cities were enforced under the Propiska Act (which was the same as housing and work permits for large cities, which were difficult to issue and receive for applicants).

The implementation of the national housing policy by creating new towns in the former Soviet Union (due to absorbing $35 \%$ of the population growth of the Soviet Union in such towns) has been relatively successful, because (at the regional level, they also reduced the load of densely populated cities). And also acquired new models for towns such as mining towns, industrial towns, and dormitory 
towns. (Richard Peiser, 2021) ${ }^{[24]}$ One of the characteristics of the new towns of the Soviet Union is the lack of ecological segregation. According to experts in most cases, the upper class, middle class, and workers may live in a neighborhood or even a building. Another feature of them is the construction of railways and the expansion of centers of activity and urban centers along with the development of railway centers.

In fact, the reasons for the relative success of the creation of new towns in the former Soviet Union were due to the correct national housing policies of this country, in the sense that these new urban settlements were conveniently located in a tie with other cities (especially through railways), ecologically inseparable. There were different strata of the people and different land uses were formed according to different strata. In addition, policies such as raising salaries and creating job opportunities were given sufficient attention, and most importantly, they had the support of the government.

\section{Egypt}

The policy of creating new towns in Egypt was adopted after the Arab-Israeli war (1973), the policy was implemented in Cairo, the capital of Egypt, for providing housing to 6.5 million people by the year 2000. Among the new towns of Egypt, we can mention the 10th of Ramadan, the 15th of May, Sadat, the 6th of October, Borg El Arab, and others. (Richard Peiser, 2021) ${ }^{[24]}$.

The criterion for locating Egypt's new towns has been the selection of desert lands to protect scarce agricultural land, and the policy aims to prevent the inflow of migrants to the Cairo metropolitan area and to direct the unintended and unplanned urbanization process in the country to a balance urban settlement system

In addition to the stated goals, the initial purpose of the new towns in Egypt had economic aspects; Because the World Bank had made such recommendations for lending to embryos. (Anthony Alexander, 2009) [6] Evaluations of Egypt's new towns show that they have not been very successful in countering to control the growth of large cities, non-destruction of agricultural land, decentralization, and regional development, while completed at great cost. Therefore, it can be concluded that the policy of creating new towns in Egypt has practically failed. (مروى, 1381) ${ }^{[34]}$. The reason for the failure of the new towns of Egypt was that the implementation of many programs for the development of the towns was not accompanied by financial support, necessary financial resources, specialized manpower, and the necessary administrative capacity and adequacy.

\section{Iran}

The urban population of Iran increased from about 20.6 percent in 1900 to more than 61.3 percent in 1996 at the same time during this period the country's urban network was disrupted and the concentration of population in the large cities is the most important feature of the urban system of this period so that the population of the five major cities of Iran (Tehran, Mashhad, Isfahan, Tabriz, and Shiraz) Increased in compare to the total population of the country from 16.4 percent in 1966, to 20.2 percent in 1996. (Keramatullah Ziyari, 1999) ${ }^{[13]}$.

Hence, this process has led to the expansion of suburbanization in large cities likewise, the growth of satellite towns and unplanned towns around such cities. Comprehensible integrated planning is essential in order to improve the quality of life of citizens and urban space also to restrain suburbanization and control the formation of unplanned towns around large cities, which led the necessity of forming and planning new towns.

The history of creating new towns in Iran dates back to a long-gone era. In this regard, we can mention many towns, which have been created in a certain time frame and are somewhat compatible with the definition of new towns, such as Bishapour, Soltanieh and etc. (فريدون \& رسول ربانى, 2002) ${ }^{[33]}$.

In the period before the Islamic Revolution (1921-1978), Iran witnessed the emergence of new towns that were built in various forms and purposes.

Such cities include:

1. New industrial-organizational towns such as Abadan, Andimeshk, Poladshahr, Piranshahr, Bandar Shahpour, ..etc.

2. Political-military new towns: such as Zahedan and Nowshahr.

3. New towns rebuilt after the earthquake such as Qojan and Salmas.

New towns of Post Islamic Revolution in Iran were created in order to manage population overflows, decentralization of large and urban cities, and meet the housing needs of lowand middle-income groups. (اردشيرى مهيار, 1378)

The reasons for the failure of new towns in Iran should be seen in the macro policies of urban development, the lack of coordination of planning at different levels, managerial weakness in the administrative structure, implementation of these projects especially in terms of the financial system and finally the limitations due to lack of identity of new towns. (ZIARI, 2002) $^{[27]}$.

\section{Causes of success and failure of new towns in different countries}

In fact, in many Third World countries, the creation and planning of new towns in the postwar era were not very successful, because the creation of new towns in Third World countries is more due to the inability of the officials to solve many urban problems of existing cities. (Pierre Merlin, 1971) ${ }^{[20]}$ Honestly, these countries didn't lay the first stone for the creation of new towns according to the national and regional needs also they have not provided a platform for cultural, social programs for it. Whereas many of the leading or developed countries in urban planning and management have provided such grounds, both at the national and regional levels. Moreover, the policy-making and planning system also considered their social and cultural systems; And as a result, the formation of such planning in such countries has been largely successful.

Hence, countries such as the United Kingdom, South Korea, the former Soviet Union, and some others that have been successful in creating new towns may have been due to the fact that the experiences of urban development models in new towns had reached a point where they were able to implement. However, many third-world countries, such as Egypt, Iran, and some others, have created new towns without the required knowledge and lacking necessary platforms, while in practice they did not have the ability to do so. Therefore, as a result, they have not been successful in this field. 


\section{The process of success or failure of creating new towns} Considering that evaluation is a kind of educational process in which an attempt is made to provide reasons and evidence indicating the advantages and disadvantages of certain plans, and new approaches are obtained to prepare better solutions. (Fathi \& Ghabelerahmat, 2016) ${ }^{[11]}$ Now, considering this fact, the process of planning new towns in countries that succeed or fail in the creation of new towns can be evaluated and studied. This process is shown in Figures 1 and 2.

From the evaluations of successful or unsuccessful countries in the creation of new towns, it can be concluded that the success of new towns is more directly related to the population acceptability of these towns in terms of meeting the predictions made; and the population density of new towns are also a follow the development coefficient which is followed out the exponential model. (AMINI et al., 2014) [5].

Therefore, it can be expected that with the provision of infrastructure and urban services and the establishment of employment in new towns, the possibility and ability to attract population in these towns will increase rapidly and reach the projected thresholds. However, the selection of immigrants to new towns must be done carefully and with the right criteria to prevent reverse migration, because it is more difficult to retain immigrants than to allocate them.

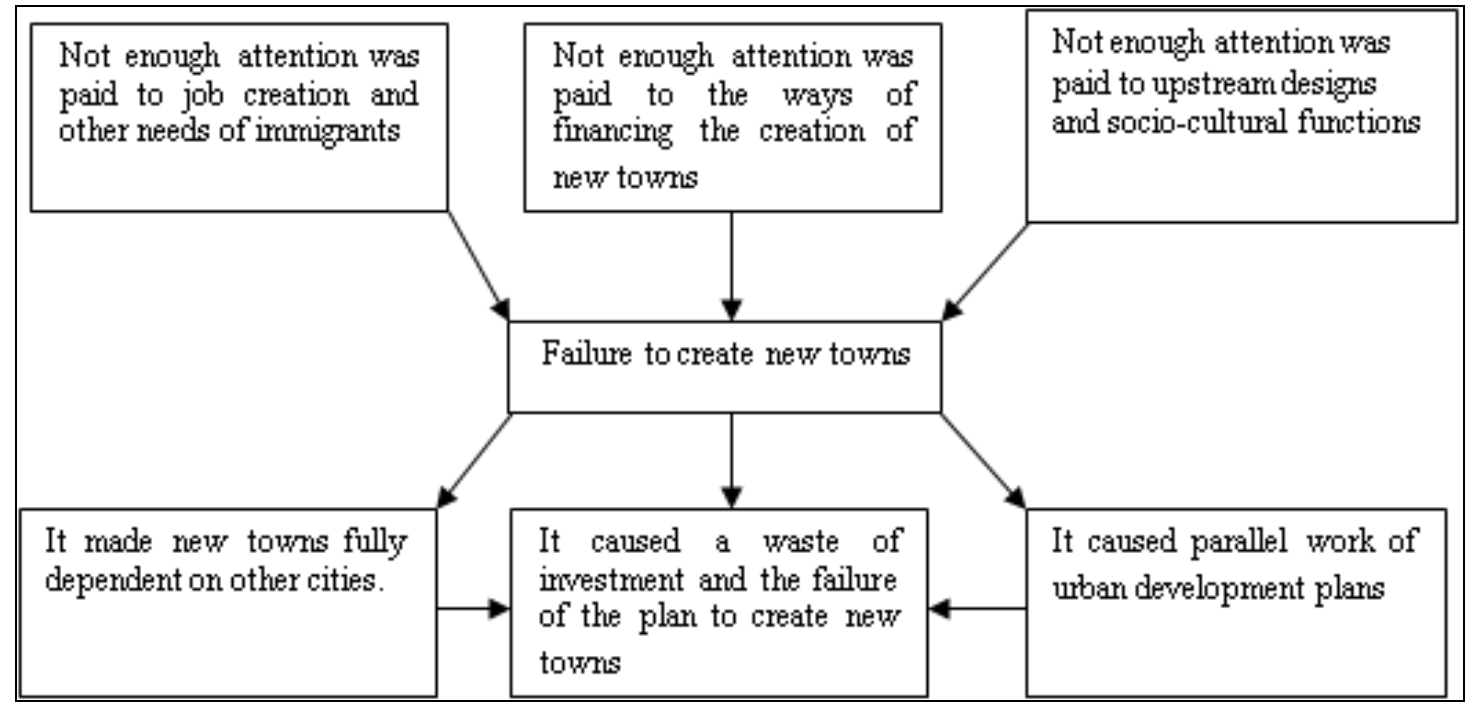

Fig 5: Reasons for the failure of new towns in some countries in the second half of the twentieth century. (Mrawi Isazada, 2010) ${ }^{[17]}$

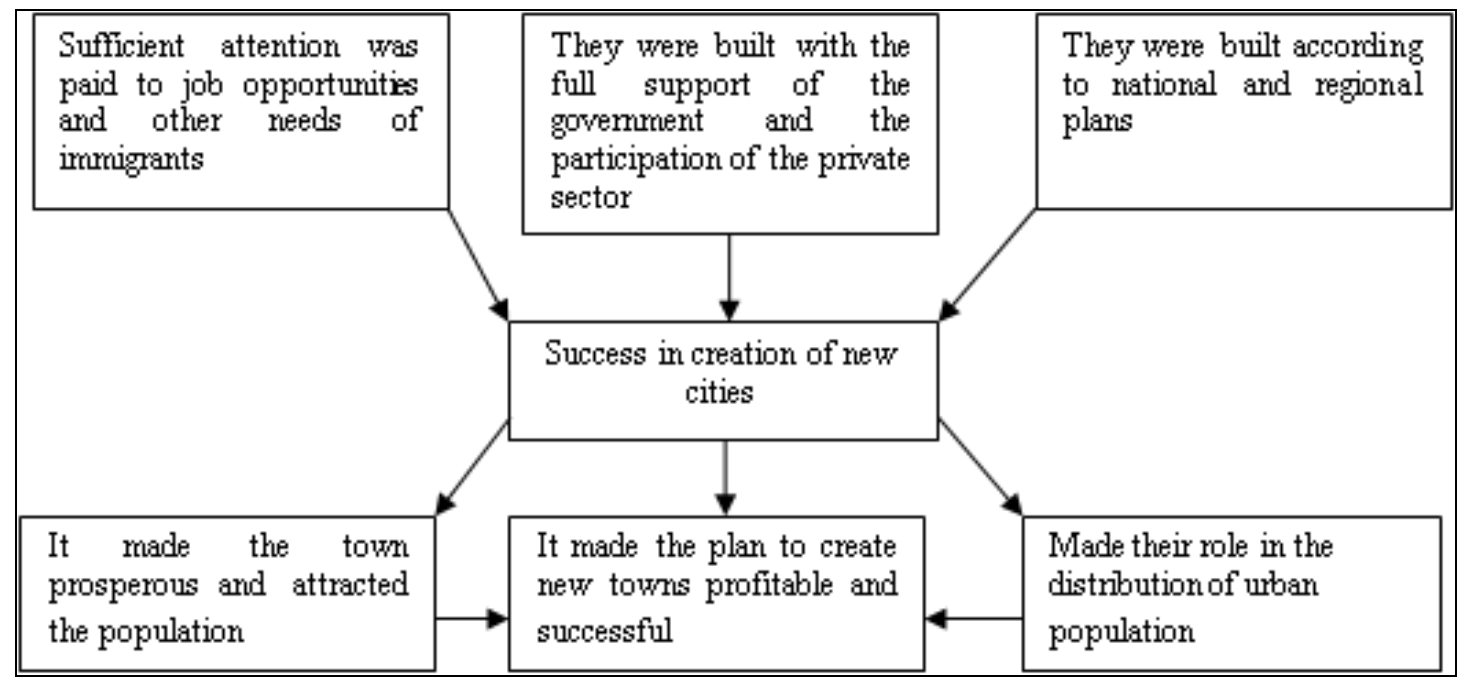

Fig 6: Reasons for the success of the creation of new towns in some countries in the second half of the twentieth century. (Mrawi Isazada, 2010) ${ }^{[17]}$.

\section{Conclusion and suggestions}

To conclude, according to the authors, the success in creating new towns can be traced in the form of the following approaches:

\section{Determining the location of new towns in urban development models}

The new town should be the embodiment of the order and pattern of the old cities. This requires that the new town should be constructed according to national and regional plans and upstream strategies, and must have a specific place in urban development policies, such things also should be taken in mind in urban development models that urban development models should not be static plans, nonetheless should be presented in the form of dynamic urban plans with flexibility. This means that upstream and downstream plans and designs must complement each other in addition to systematic linking and harmony. 


\section{The construction of new towns must be cost-effective}

The comprehensive development plan of the new town, in addition to spatial, social, and economic planning, must also have a financial plan. Therefore, financial self-sufficiency is essential for the construction of new towns. Governments can help finance new towns through grants and long-term low-interest loans, as well as boosting private sector partnerships with foreign investors, to carry out new towns projects and make them affordable.effective-and cost As mentioned, the experiences of some countries in which the creation and expansion of new towns have been relatively successful, show that these programs have been operationalized and implemented.

\section{Strengthening the identity in the new towns}

In creating new towns, attention must be paid to the identity of the town. The sustainability of the new town is most affected by the sense of citizens they feel in their place of residence. Therefore, strengthening the identity and stability of new towns depends on strengthening the urban attractions of such population centers.

For this purpose, the following solutions can be useful Attracting different groups of people to the new town. In this case, according to each social stratum, different job opportunities, land in different portions and prices, different urban patterns, and different services and facilities should be provided.

Providing co-housing employment (employment along with housing) as well as increasing income for most households in the new town by providing more diverse job opportunities.

Strengthening transport infrastructure (inner-city and intracity transportations) in new towns, which is necessary for this purpose to build roads and facilitate transportation.

Providing different land uses to give identity for a new town before inhabiting it. Also with the construction of residential neighborhoods simultaneously various land uses should be provided, including cultural, educational, health, welfare, facilities, and so on.

\section{References}

1. Abir Bandyopadhyay. Town Planning (2nd ed.,). Arunbha Sen Books \& Allied (P) ltd, 2010, 1.

2. Aeeni M, Zabihi H, Saeideh Zarabadi ZS. An Assessment Model for Challenges of Urban Management System in Iranian New Towns, Based on Interpretive Structural Modeling (ISM) Approach. BAGH-E NAZAR. 2019;16(75 \#r00576):33-46. https://www.sid.ir/en/journal/ViewPaper.aspx?ID=6903 21

3. Ajza Shokouhi M. A Staged Development Model For New Towns: A British Experience. Geographical Research. 2002;17(2-3(65-66)):95-115. https://www.sid.ir/en/journal/ViewPaper.aspx?ID=3518 0

4. Ajza Shokouhi M. The Role of Employment in the Development of New Towns in Britain. Geographical Research, 2003;17(4(67)):0. https://www.sid.ir/en/journal/ViewPaper.aspx?ID=3519 3

5. Amini E, Borumand M, Rouhafza F. Evaluation Factors In Increasing The Quality Of Public Spaces In New Cities (Case Study: Parand New City). Environmental Based Territorial Planning (Amayesh), 2014;7(26):89-
110.

https://www.sid.ir/en/journal/ViewPaper.aspx?ID=4166 69

6. Anthony Alexander. Britain's New Towns Garden Cities to Sustainable Communities (1st ed.,) Routledge, 2009, 1. https://www.routledge.com/Britains-NewTowns-Garden-Cities-to-Sustainable-

Communities/Alexander/p/book/9780203875650

7. Bastie JDB. La Ville (2nd ed.). Faculty of Art, Tehran University, 1997.

8. Bora RS. Migrant Informal Workers: A Study of Delhi and Satellite Towns. Modern Economy, 2014;05(05):562-579. https://doi.org/10.4236/me.2014.55053

9. Calloway DM, Faghri A. Complete Streets and Implementation in Small Towns. Current Urban Studies. 2020;08(03):484-508. https://doi.org/10.4236/cus.2020.83027

10. David Friedman. Florentine New Towns: Urban Design in the Late Middle Ages. The MIT Press, 1989.

11. Fathi S, Ghabelerahmat F. Citizenship, A Prolusion Of Social Development In New Towns (Case Of Study: Parand New Town). Journal of Iranian Social Development Studies (JISDS). 2016;8(2(30)):127-137. https://www.sid.ir/en/journal/ViewPaper.aspx?ID=5199 24

12. Hatami Nejad H. Satisfaction Measurement From Life Quality Indicators In New Cities(Case Study: New Town Mohajeran). Geographical Planing Of Space. 2017;7(23\#M00133):53-68.

https://www.sid.ir/en/journal/ViewPaper.aspx?ID=5782 50

13. Keramatullah Ziyari. Planning of New Towns (1st ed.). Tehran University Press, 1999, 1.

14. Liu M. The Strategic Thinking on Promoting the Specialized Towns' New-Style Urbanization Construction in Guangdong Province. Journal of Service Science and Management. 2016;09(06):501511. https://doi.org/10.4236/jssm.2016.96052

15. Luo D, Zhang Y. Policy Tool Model and Its Application in the Governance of Characteristic Towns. Open Journal of Social Sciences. 2020;08(07):232-244. https://doi.org/10.4236/jss.2020.87019

16. Mayunga SD. Suitability Analysis of Satellite Towns Using Saaty Model and Geographical Information System (GIS). Journal of Data Analysis and Information Processing. 2018;06(01):1-14. https://doi.org/10.4236/jdaip.2018.61001

17. Mrawi Isazada. The need for Creation of New Towns: Transformations in 1945 onward. Mohammad Negahban, 2010, 1.

18. Niazi AJ. Evaluation of Distribution Pattern in Urban Services Using Network Analyse and Nearest Neighborhood Index Based on Distributary Justice Approach: Case of Kabul City. KPU International Journal of Engineering \& Technology. 2021;1(1):115136.

19. Ostrowski W. L'urbamisme contemporiam des origines o'la charte d'Athenes (2nd ed.). Tehran University Press, 2000.

20. Pierre Merlin. New towns: Regional planning and development (1st ed.,). Methuen, 1971, 1. https://www.amazon.com/New-Towns-PierreMerlin/dp/0416168108/ref=sr_1_1 ?keywords=9780416 
$168105 \&$ linkCode $=$ qs $\& q i d=1640164958 \&$ s $=$ books $\& s r$ $=1-1$

21. Pollalis SN, Kouveli A, Orfanos Y, Tzioti O. Planning a Sustainable New City. Journal of Building Construction and Planning Research. 2014;02(01):5058. https://doi.org/10.4236/jbcpr.2014.21005

22. Razmi MH, Rahimiyoun ALIA. Study And Presenting Policies For Population Pull And Population Stability In New Satellite Towns (Case Study: Sadra New Town). Haft Hesar Journal Of Environmental Studies. 2013;1(2):37-46. https://www.sid.ir/en/journal/ViewPaper.aspx?ID=3255 20

23. Rego C, Caleiro A. On the Spatial Diffusion of Knowledge by Universities Located in Small and Medium Sized Towns. I Business. 2010;02(02):99-105. https://doi.org/10.4236/ib.2010.22012

24. Richard Peiser AF. New Towns for the Twenty-First Century: A Guide to Planned Communities Worldwide (2nd ed.,). University of Pennsylvania Press, 2021, 1. https://www.amazon.com/New-Towns-Twenty-FirstCenturyCommunities/dp/0812251911/ref=sr_1_1?keywords $=9$ $780812251913 \&$ linkCode $=q s \& q i d=1640164460 \& s=$ bo oks\&sr $=1-1$

25. United Nations, Department of Economic and Social Affairs. World Urbanization Prospects: The Revision, 2018.

26. Yaran ALI, Mohammadi Khoshbin H. The Analysis Of Self-Sufficiency In New Cities Comparing Iran's Experience (Hashtgerd New City) And South Korea. Iranian Architecture And Urbanism. 2012;(4):99-112. https://www.sid.ir/en/journal/ViewPaper.aspx?ID=4396 63

27. Ziari K. Planning and Functioning of New Towns in Iran. Journal of Environmental Studies, 2002;28(29):12-25.

https://www.sid.ir/en/journal/ViewPaper.aspx?ID=2852 0

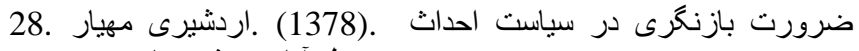

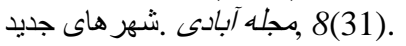

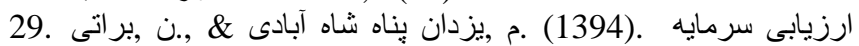

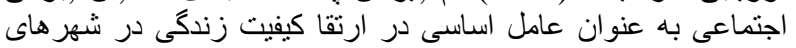

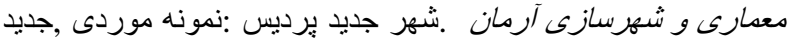

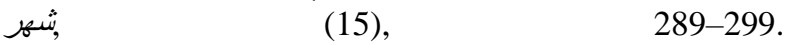
https://www.sid.ir/fa/journal/ViewPaper.aspx?ID=2729 57

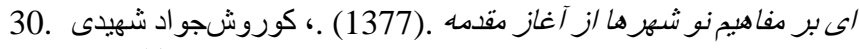

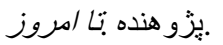

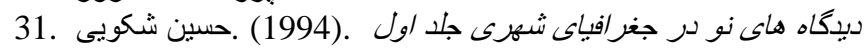
(2nd ed., Vol. 1). سمت (19).

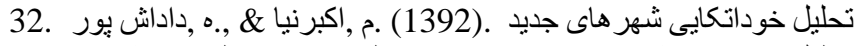

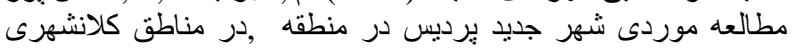

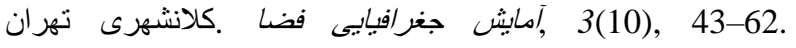
https://www.sid.ir/fa/journal/ViewPaper.aspx?ID=2487 53

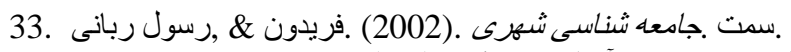

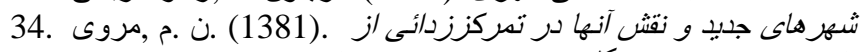

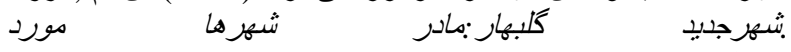
https://ganj.irandoc.ac.ir//\#/search?keywords=شهر هارد های 